\title{
Multisource Inverter Based Energy Management System in Electric Vehicle
}

\author{
Yogesh Mahadik, K. Vadirajacharya
}

\begin{abstract}
Day after day, natural energy sources are dwindling. Energy saving plays a crucial role in reducing the amount of pollution. Electric Vehicle consists of an energy storage system. Full car efficiency relies on energy storage system capacities. Driving cycle with high specific energy requirements that are met by the source of the battery. The battery will supply specific peak power demands with great current stress. Great present stresses directly affect battery life as a battery with less power density. It was discovered from the literature that supercapacitor has elevated power density and can be used as a specific power supply energy during the driving cycle's peak energy requirements. The supercapacitor can be used during car break to store dynamic power storage source. All power/energy requirements of the driving cycle have simultaneously regulated the operation of both sources.

A new multi-source inverter can be used to improve the vehicle's driving cycle. During an unstable case triggered by the power scheme, it can also use as a vibrant energy restore. Paper is a multisource inverter (MSI) analogy, MSI simulation, and multi-source inverter operation with hardware outcome debate.
\end{abstract}

Index Terms- Multisource Inverter (MSI), Battery, Ultracapacitor (UC), Driving cycle, Efficiency, Energy storage system (ESS).

\section{INTRODUCTION}

A hybrid electric vehicle with a storage scheme of multisource inverter type is beneficial and responsive to dynamic variations in the electric vehicle's driving cycle. The battery used to meet long-term demand for energy and the ultra-capacitor meets particular maximum power requirements. This article involves applying multisource inverter-based ESS to regulate approach intended for source features based on the Ragon plot. The power-sharing towards load depends on the load torque and the state of charge of the UC and Battery controlled using inverter control. A simulation is performed using MATLAB/ SIMULINK environment. Novel inverter multi-source terminology validated by the prototype. Active sharing improves the driving cycle, weight reduction ESS effectiveness.

\section{EXISTING STRATEGIES}

Ragon graph created an idea for comparing different source with efficiency. From the Ragon chart it is clear that batteries have a relatively high density of energy but a lower density of power, on the contrary, the UC has a lower density

Revised Version Manuscript Received on 16 September, 2019.

YogeshMahadik, Research Scholar, DBATU, Lonere.Maharashtra, India.

(Email: yogi_maha@yahoo.co.in)

Dr. K. Vadirajacharya, Professor, HOD Electrical DBATU, Lonere,

(Email: kvadirajacharya@dbatu.ac.in) Maharashtra, India.

of energy with a sufficiently high density of power. Moreover, UC's life is much higher than its battery life. Also, UC's have low-temperature performance compared to batteries. The general efficiency of the scheme improved by mixing both

sources[1-4].

\subsection{Passive parallel}

It's the easiest ESS setup. Without any converter or inverter, the battery and UC bank was linked to the dc connection in this setup. The two sources of energy are connected here in parallel.

$$
\mathrm{V}_{\mathrm{B}}=\mathrm{V}_{\mathrm{U}}=\mathrm{V}_{\mathrm{DC}} \text {. }
$$

The benefits of this setup include ease of application, and the DC / DC converter or inverter is not needed. We can not efficiently use ultracapacitor with this analogy.

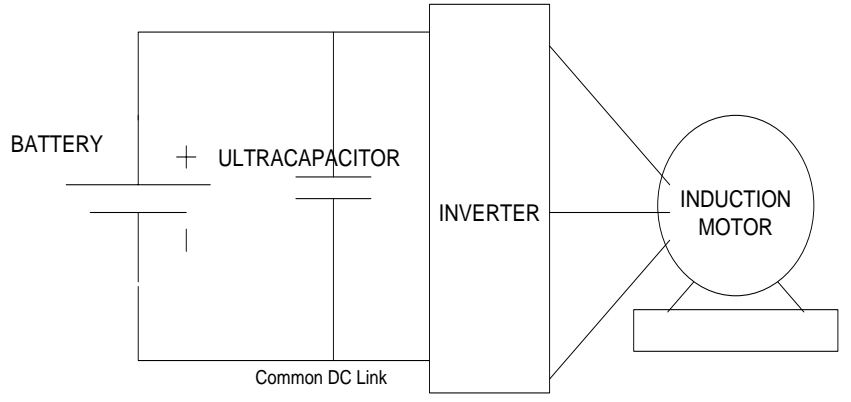

Fig.1 Basic passive parallel hybrid configuration.

\subsection{Battery/ UC configuration}

The battery connected to the DC link via DC/DC converter and the UC is connected directly to the $\mathrm{dc}$ connection. The benefits of this are the voltage, or a battery can be kept lower or higher than the UC voltage.

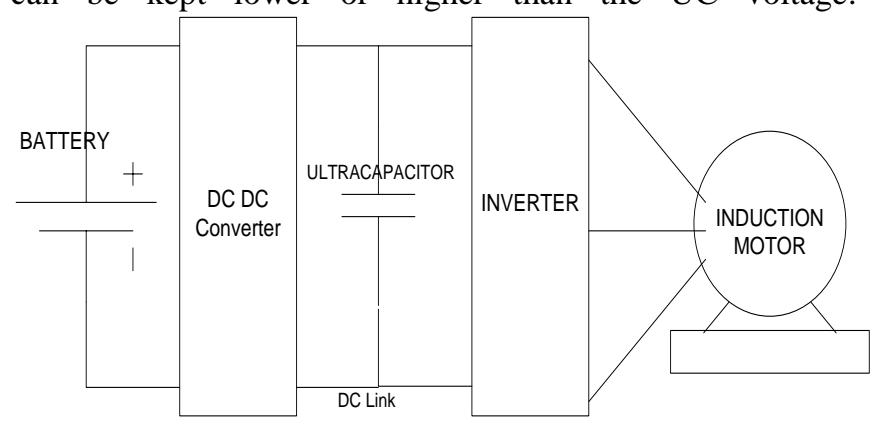

Fig.2 Battery/UC configuration.

Published By: 


\subsection{UC/ Battery configuration}

In this configuration UC connected to the dc link through the DC/DC converter and battery is directly connected to the DC link.

The advantage of this configuration is that the voltage of UC can be used with a versatile range, but the limitation of this configuration is that the converter needs to be the large size for handle the power of UC therefore, the adverse effect of a cost of the converter.

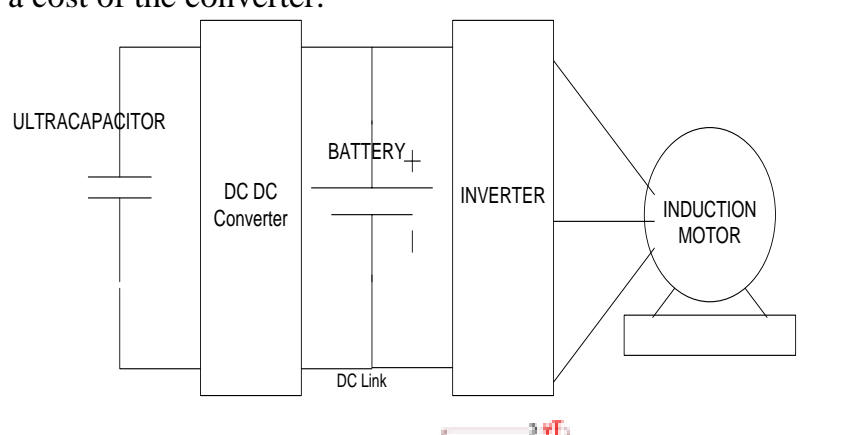

Fig.3 UC/battery configuration.

The analogy is developed using MATLAB simulation

\subsubsection{Simulation of the system}

Basic simulation performed for UC / battery configuration with a simulation time of 1000 seconds with Battery connected to Load, whereas UC connected through a DC-DC converter. Gradually load increased with time intervals of 300 sec. Results are observed to identify the dynamic response of the ultracapacitor for stated analogy (3. 3.).

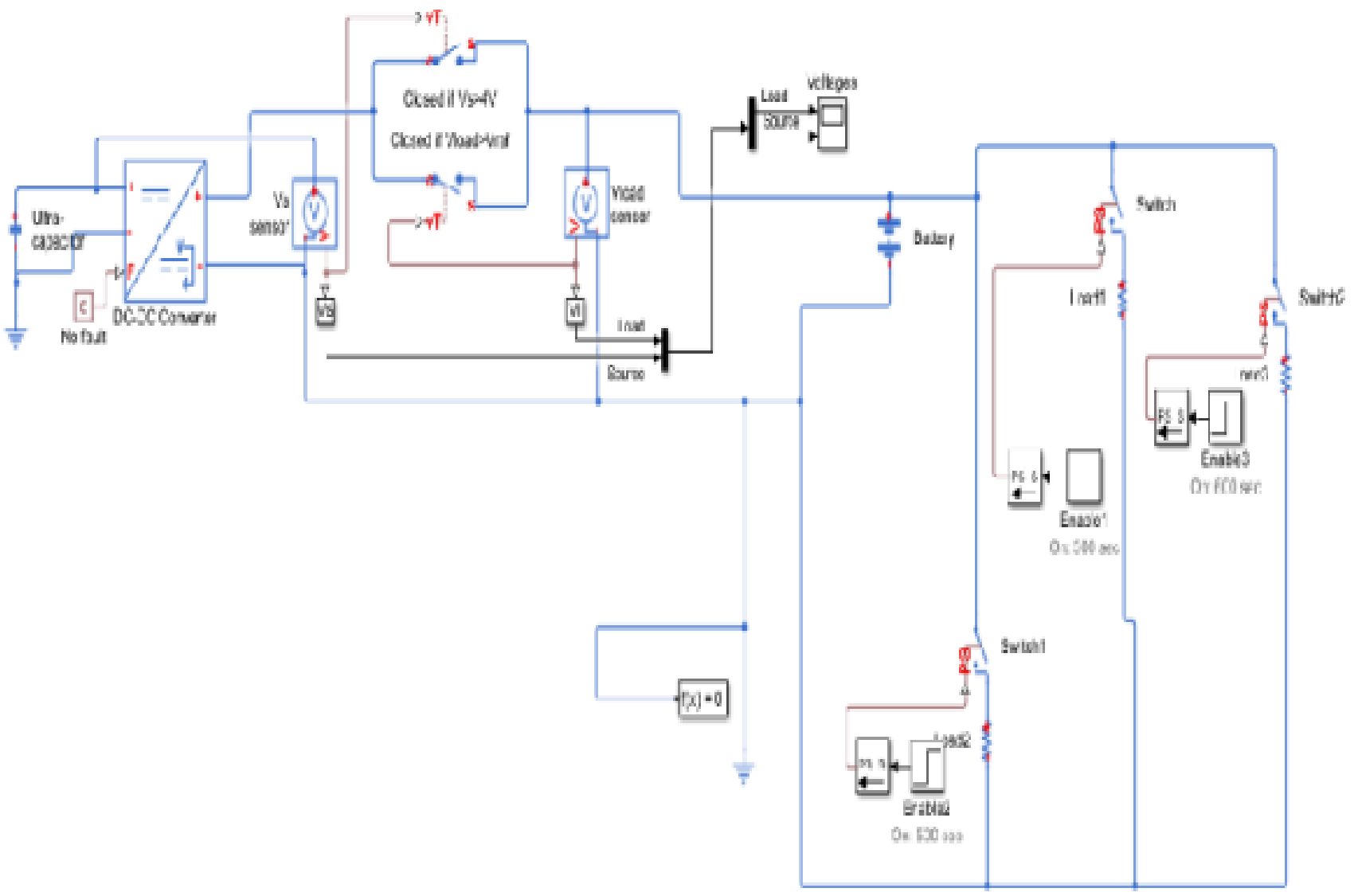

Bottery *ultrecepicitor

Fig.4 Simulation of UC/Battery Configuration 


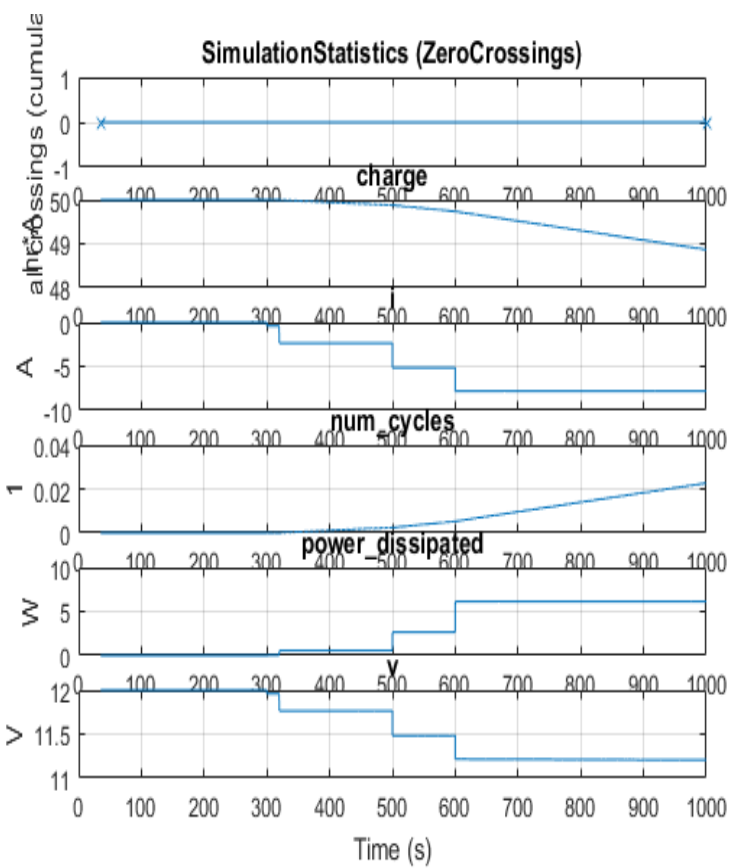

Fig. 5 Discharging of Ultracapacitor according to load.
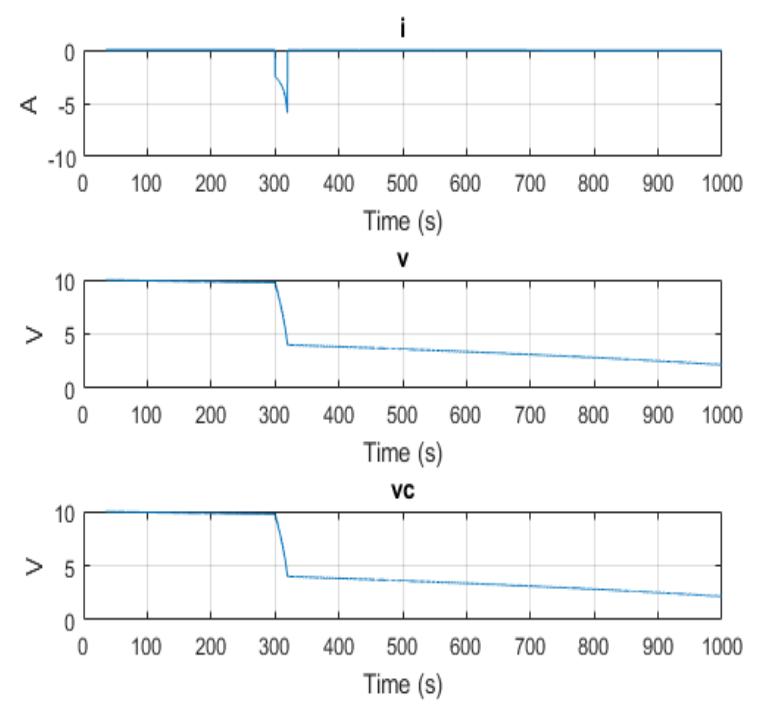

Fig. 6 Discharging of Battery according to load.

Peak power demands (Fig. no. 6) at $300 \mathrm{sec}$ and $600 \mathrm{sec}$ is handled by ultracapacitor discharging. Peak current requirements are fulfilled by ultracapacitor whereas base requirements dealt with by Battery as an energy source.

Two converters were used in the existing system. Converter losses can be minimized using the direct connection of sources with 3 phase load, which is analyzed by the proposed method.

\section{PROPOSED MULTI-SOURCE INVERTER}

This topology's primary aim is to cascade multiple dc sources with connection to the three-phase AC load. In this case, two DC sources are connected, namely Battery (VB) and Ultracapacitor (VU); this multi-source inverter consists of 12 microcontroller-controlled IGBTs. The primary benefit of this topology is that it does not add any additional stages between load and sources, resulting in improved electric vehicle efficiency by enhancing the fulfillment of energy and power demand. Source current regulated according to driving cycle torque demands in the suggested control approach. Three switching modes are chosen here with microcontroller based on Electric Vehicle acceleration, cruising and breaking. There are three operating modes regarding switching states

Mode 1: $\mathrm{V}_{\mathrm{B}}$ is not used and switches $\mathrm{S}_{\mathrm{L} 1}, \mathrm{~S}_{\mathrm{L} 2}, \mathrm{~S}_{\mathrm{L} 3}$ and $\mathrm{S}_{\mathrm{U} 11}$, $\mathrm{S}_{\mathrm{U} 12}, \mathrm{~S}_{\mathrm{U} 13}$ enable $\mathrm{V}_{\mathrm{U}}$ to supply the motor;

Mode 2: The switches $\mathrm{S}_{\mathrm{U} 1}, \mathrm{~S}_{\mathrm{U} 2}, \mathrm{~S}_{\mathrm{U} 3}$ and $\mathrm{S}_{\mathrm{U} 11}, \mathrm{~S}_{\mathrm{U} 12}, \mathrm{~S}_{\mathrm{U} 13}$ would allow $V_{B}$ to supply the motor with charging $V_{U}$. The output voltage is equal to $\mathrm{V}_{\mathrm{B}}-\mathrm{V}_{\mathrm{U}}$;

Mode 3: The switches $\mathrm{S}_{\mathrm{U} 1}, \mathrm{~S}_{\mathrm{U} 2}, \mathrm{~S}_{\mathrm{U} 3}$ and $\mathrm{S}_{\mathrm{L} 1}, \mathrm{~S}_{\mathrm{L} 2}, \mathrm{~S}_{\mathrm{L} 3}$ enable $\mathrm{V}_{\mathrm{B}}$ to supply the motor, and $\mathrm{V}_{\mathrm{U}}$ is not used.

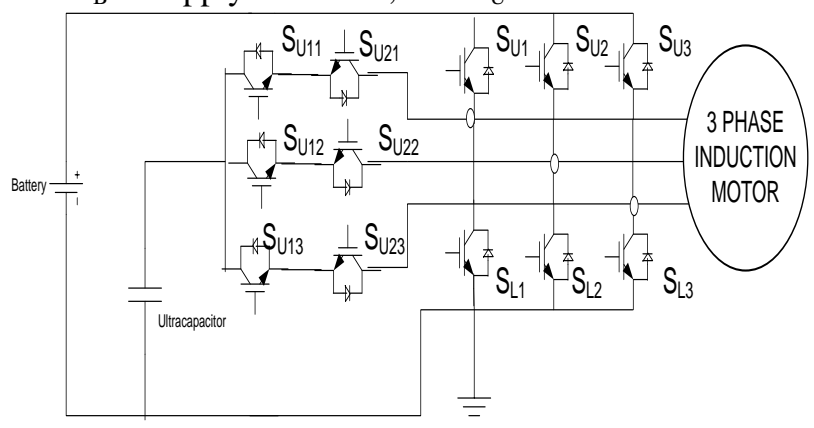

Fig No.7 Multisource Inverter

The voltages $\left[\mathrm{V}_{10}, \mathrm{~V}_{20}, \mathrm{~V}_{30}\right]$ are functions of the state of the switches and input voltages:

$$
\begin{array}{ll}
\mathrm{V}_{1 \mathrm{O}}= & \mathrm{E}_{\mathrm{SU} 1} \mathrm{~V}_{\mathrm{B}}+\mathrm{E}_{\mathrm{U} 11} \mathrm{~V}_{\mathrm{U}}-\mathrm{Z}_{\mathrm{a}} \mathrm{i}_{1} \\
\mathrm{~V}_{2 \mathrm{O}}= & \mathrm{E}_{\mathrm{U} 2} \mathrm{~V}_{\mathrm{B}}+\mathrm{E}_{\mathrm{U} 12} \mathrm{~V}_{\mathrm{U}}-\mathrm{Z}_{\mathrm{b}} \mathrm{i}_{2} \\
\mathrm{~V}_{3 \mathrm{O}}= & \mathrm{E}_{\mathrm{U} 3} \mathrm{~V}_{\mathrm{B}}+\mathrm{E}_{\mathrm{U} 13} \mathrm{~V}_{\mathrm{U}}-\mathrm{Z}_{\mathrm{c}} \mathrm{i}_{3}
\end{array}
$$

Where $\mathrm{Z}=$ impedance of load

$\mathrm{E}_{\mathrm{SU} 1,2,3}$ and $\mathrm{E}_{\mathrm{U} 11,12,13}=$ Switching functions Similarly input currents $\left[\mathrm{I}_{\mathrm{B}}, \mathrm{I}_{\mathrm{U}}\right]$ can be expressed as: $\mathrm{I}_{\mathrm{B}}=\mathrm{E}_{\mathrm{SU} 1} \cdot \mathrm{i}_{1}+\mathrm{E}_{\mathrm{SU} 2} \cdot \mathrm{i}_{2}+\mathrm{E}_{\mathrm{SU} 3} \cdot \mathrm{i}_{3}$ $\mathrm{I}_{\mathrm{U}}=\mathrm{E}_{\mathrm{U} 11} \cdot \mathrm{i}_{1}+\mathrm{E}_{\mathrm{U} 12} \cdot \mathrm{i}_{2}+\mathrm{E}_{\mathrm{U} 13} \cdot \mathrm{i}_{3}$ 
Table 1- Switching Combinations of $\mathrm{MSI}^{[3]}$

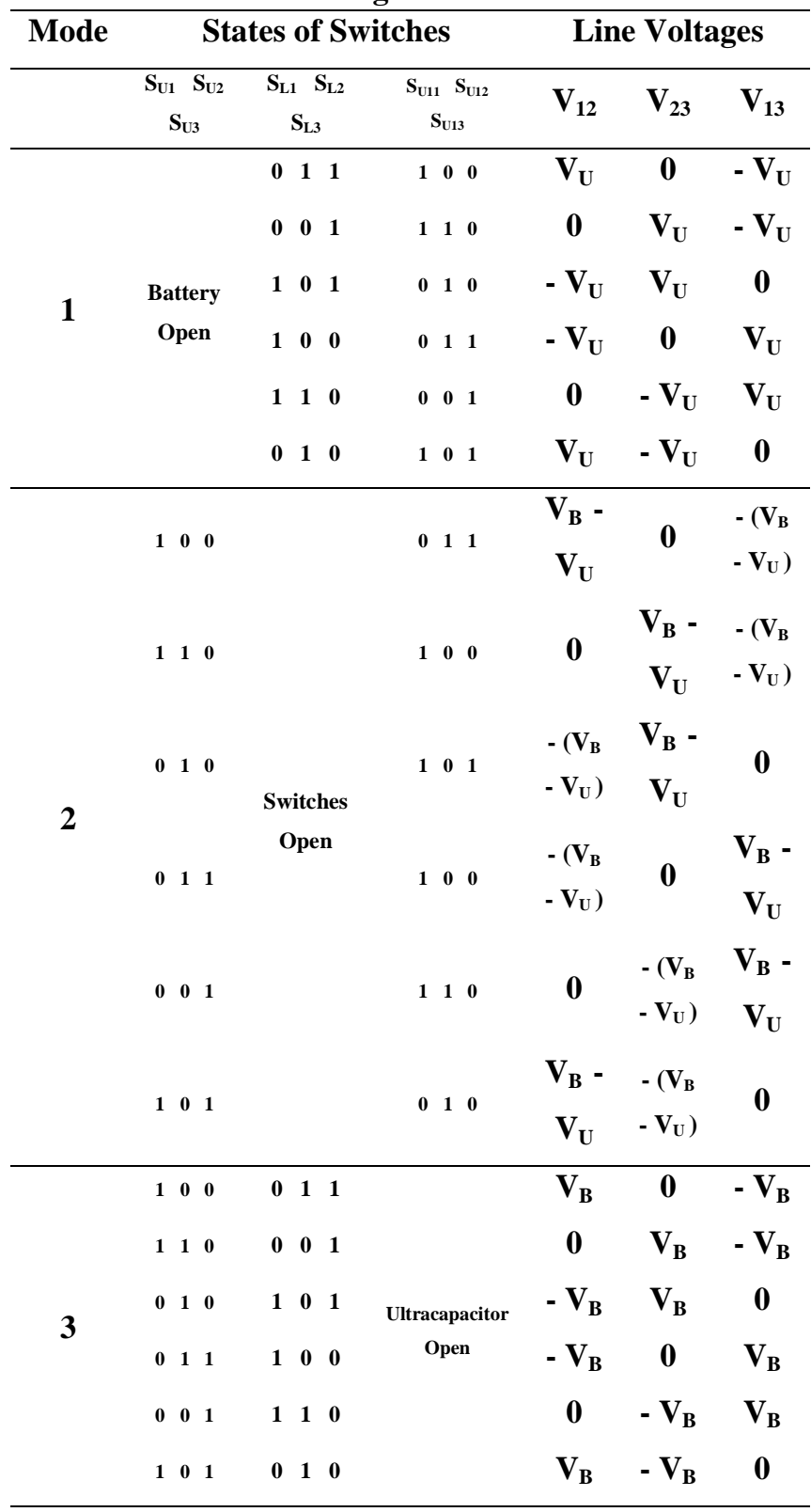

\section{PROTOTYPE DEVELOPMENT}

The hardware consists of Buffer IC (74HC244) to control modes with adjustment of duty cycle using enable signal. EN1 is used to control upper switches $\mathrm{S}_{\mathrm{U} 1}, \mathrm{~S}_{\mathrm{U} 2}, \mathrm{~S}_{\mathrm{U} 3}$. EN2 control $\mathrm{S}_{\mathrm{L} 1}, \mathrm{~S}_{\mathrm{L} 2}, \mathrm{~S}_{\mathrm{L} 3}$ whereas $\mathrm{EN} 1 *$ and $\mathrm{EN} 2 *$ are used to control $\mathrm{S}_{\mathrm{U} 11}, \mathrm{~S}_{\mathrm{U} 12}, \mathrm{~S}_{\mathrm{U} 13}$ and $\mathrm{S}_{\mathrm{U} 21}, \mathrm{~S}_{\mathrm{U} 22}, \mathrm{~S}_{\mathrm{U} 23}$ respectively. The low state (digital zero) of the latch is allowing input at latch output. Simulation is carried out using the Proteus design suit environment [27-30].

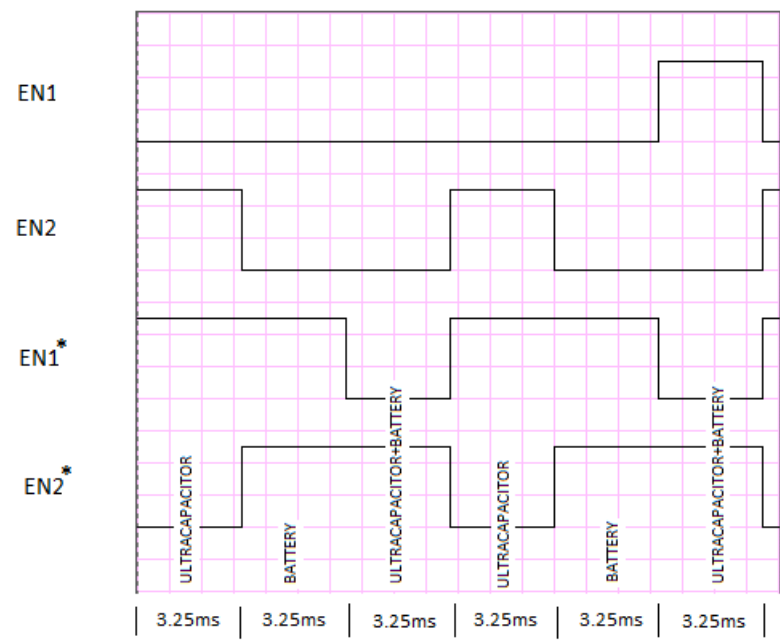

Fig. 8.Mode Control using Buffer.

MOSFET switches controlled through Latch, explained as follows.

Table 2.Latch and switch the Enable States for mode-1,2\& 3 .

\begin{tabular}{|c|c|c|c|c|}
\hline Control State & $\begin{array}{l}\mathrm{EN1}\left(\mathrm{S}_{\mathrm{U} 1},\right. \\
\left.\mathrm{S}_{\mathrm{U} 2}, \mathrm{~S}_{\mathrm{U} 3}\right)\end{array}$ & $\begin{array}{l}\text { EN2 } \\
\left(S_{\mathrm{L} 1},\right. \\
\mathrm{S}_{\mathrm{L} 2}, \\
\left.\mathrm{~S}_{\mathrm{L} 3}\right)\end{array}$ & $\begin{array}{l}\mathrm{EN1} *\left(\mathrm{~S}_{\mathrm{U11}},\right. \\
\left.\mathrm{S}_{\mathrm{U} 12}, \mathrm{~S}_{\mathrm{U} 13}\right)\end{array}$ & $\begin{array}{l}\mathrm{EN} 2 *\left(\mathrm{~S}_{\mathrm{U} 21},\right. \\
\left.\mathrm{S}_{\mathrm{U} 22}, \mathrm{~S}_{\mathrm{U} 23}\right)\end{array}$ \\
\hline $\begin{array}{l}\text { UC } \\
\text { (Charging) }\end{array}$ & ON & OFF & OFF & ON \\
\hline $\begin{array}{l}\text { Battery } \\
\text { (Discharging) } \\
\text { Battery }\end{array}$ & ON & ON & OFF & OFF \\
\hline $\begin{array}{l}\text { (Discharging) } \\
+\quad \text { UC } \\
\text { (Discharging) }\end{array}$ & ON & ON & ON & OFF \\
\hline
\end{tabular}

Switch controlled through SVPWM (Space Vector Pulse Width Modulation) technique shown in Fig. 9 below.

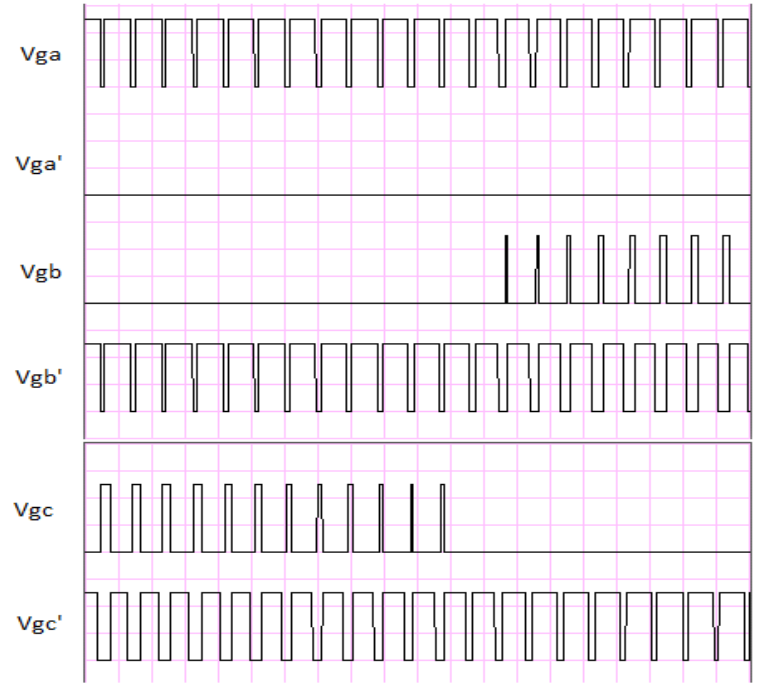

Figure 9.SVPWM Control signal generation in protease. 
The operation of the circuit is explained with a flow chart (Figure 10) as follows.
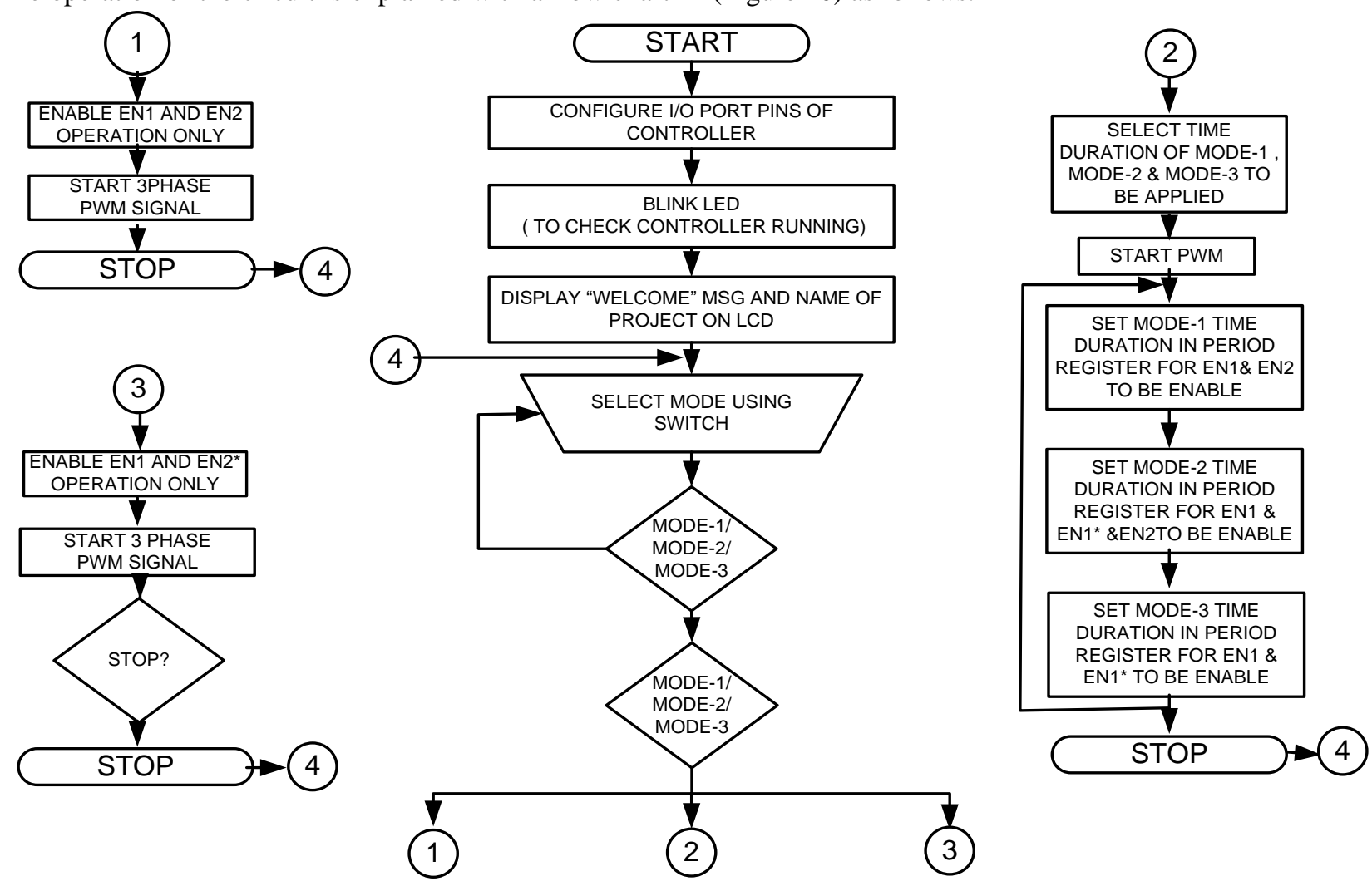

Fig. 10 Process Chart.

In the Implementation of hardware, battery and ultracapacitor drive the load (Electric motor / Grid / RL Load) in which we observe the power and energy sharing conduct during dynamic loading scenarios. Observations are made for distinct combinations of three modes (i.e., mode-1: battery as a source only, mode-2: both sources simultaneously handling the dynamic power requirement condition and mode-3: ultracapacitor as a source).

Hardware is introduced using 6 IGBTs, the three-phase inverter that provides battery energy to the AC link and the ultracapacitor bank attached to the AC connection via 6 IGBTs. Thus, the implementation uses a total of 12 IGBTs.

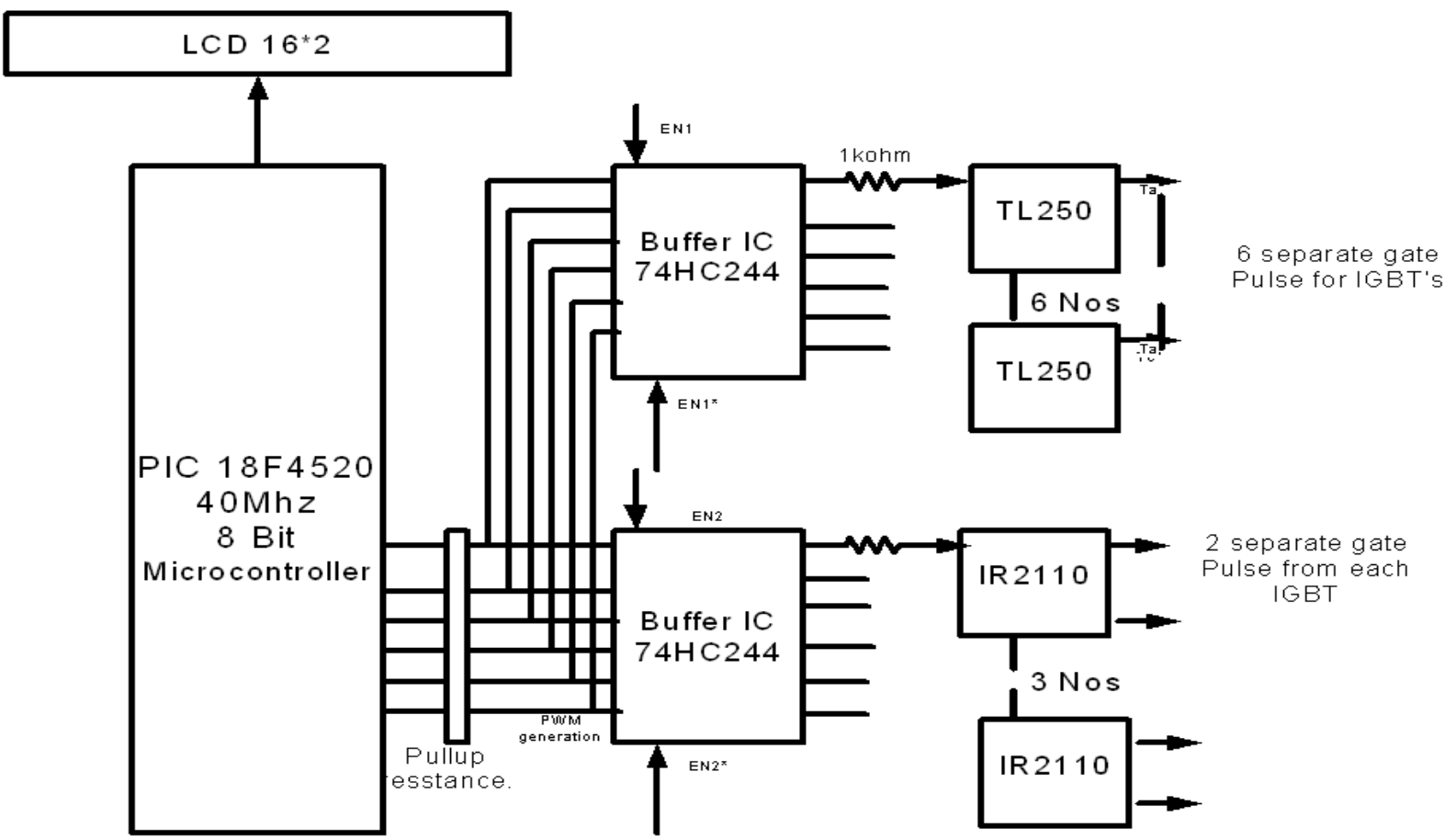

Fig. 11 Hardware implementation. 
Hardware is introduced using the three modes earlier indicated. PCB is built using express PCB software.

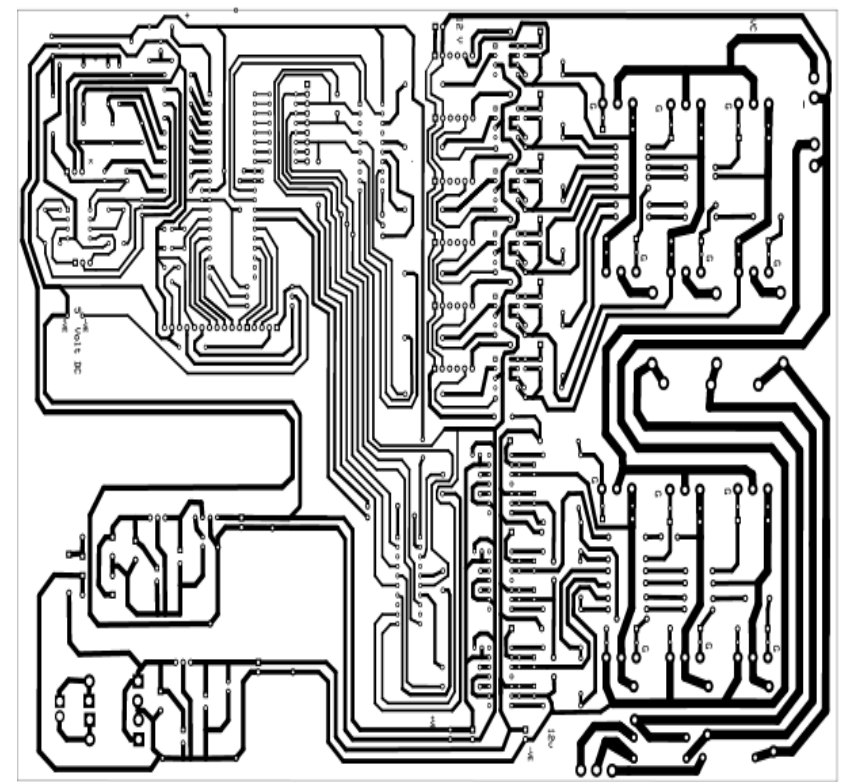

Fig. 12 .PCB layout.

Single side PCB Itched and made with parts for fastening. Using the SVPWM analogy, the 18F4520 microchip processor is used with a control approach based on a lookup table with signal generation and using dqo vectors, digital control signals created in six sectors.

Look up table with 864 states is included to decrease the controller's computing time, so we get two-level inverter output. Buffer (74HC244) is used to select the modes.

\section{RESULTS}

In this chapter, experimental findings are discussed in detail with distinct combinations of three modes. Case-1: In this case, Battery functions as a source and offers a resistive load (mode-1). Inverter voltage and current for case-1 where SVPWM-based inputs are generated from the inverter.

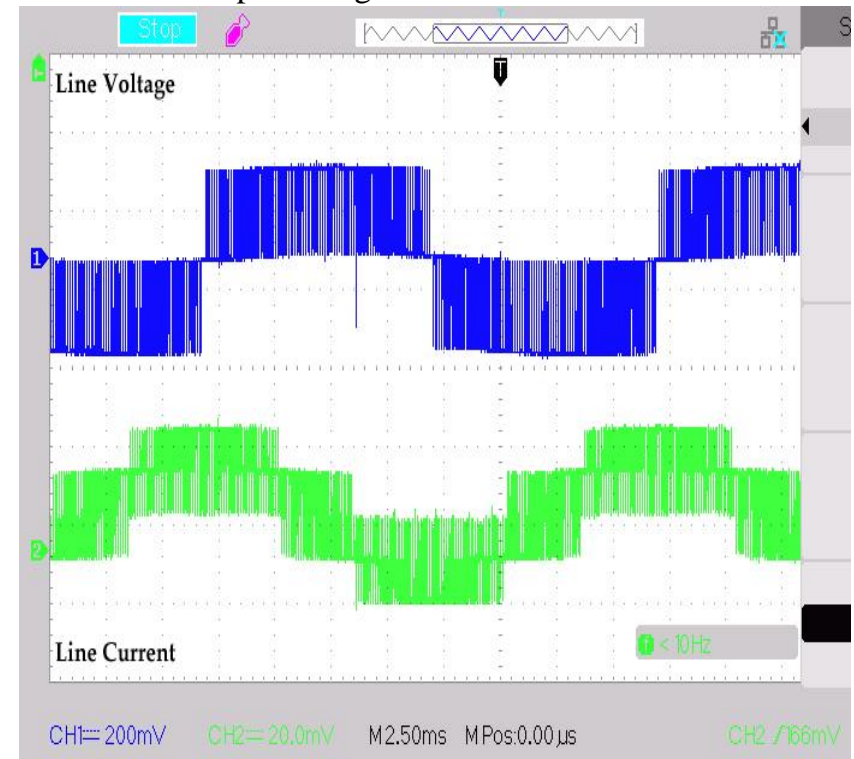

Fig.13.Line Voltage and current at the inverter output.
Input voltage obtained from the battery to inverter is $24 \mathrm{~V}$ DC. The output obtained with the line to line voltage is 12 volts with current 1.2 A (readings measured across 1 -ohm resistor connected in line with RL load). Waveform below (Figure 33) shows phase displacement between different phase voltages of the inverter.

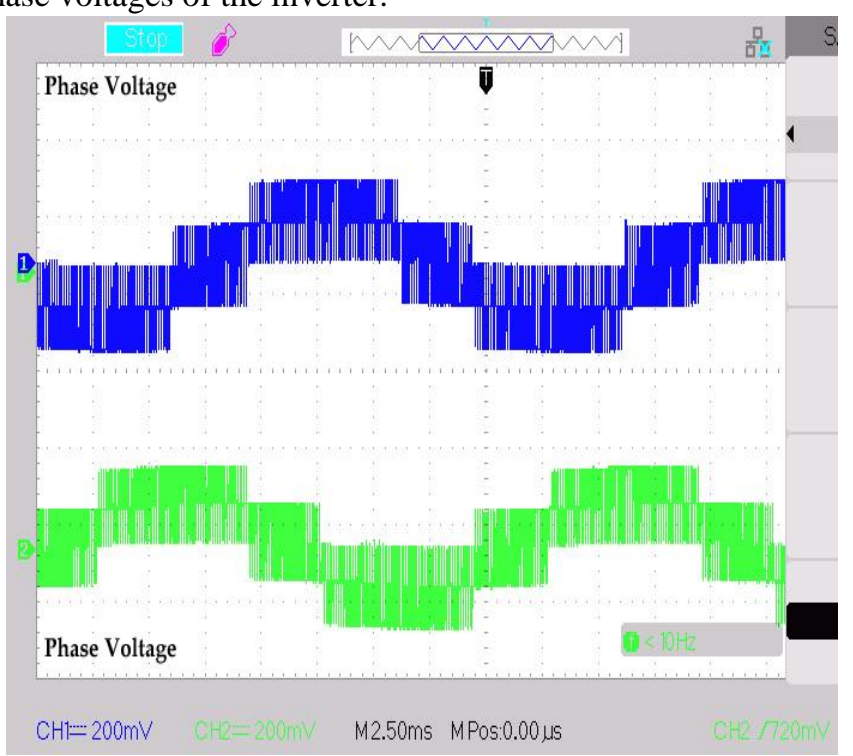

Fig.14.Phase voltages at the inverter output.

Output with input for case-1 where battery supplies power to load is as follows. Readings of battery current are noted by variation in 3 phase load with continuous, intermittent switching of $10 \mathrm{~s}$.

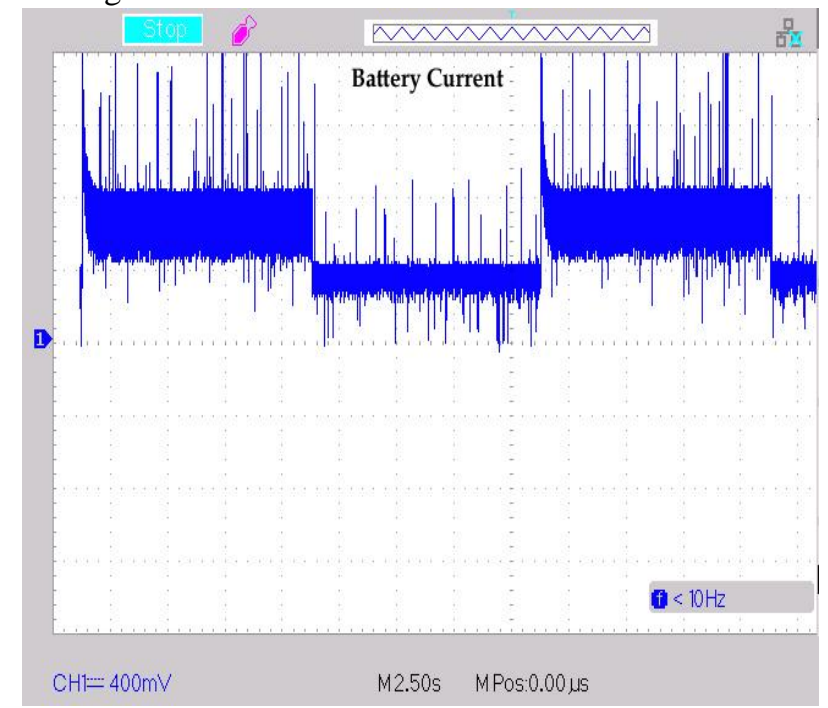

Fig.15. Battery Current.

In this case, the battery source alone fulfills the complete energy requirement. In this case, the current from the battery is $4 \mathrm{~A}$ for $5 \mathrm{~s}$ and $2 \mathrm{~A}$ for the next five intervals, giving an average battery current of $3 \mathrm{~A}$.

Case-2: You can change the mode by using latch enable signals. It is the suggested method for analyzing and interpreting results and conclusions by simultaneously implementing a mixture of distinct sources (mode-2, mode-3).

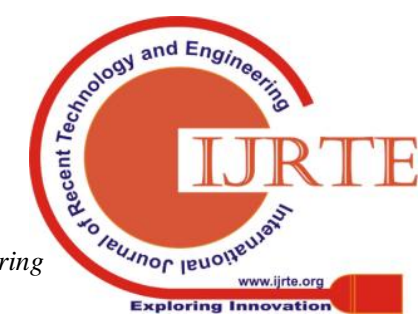


By adjusting the duty cycle of source utilization, the prototype is tested for different combinations of sources. With a potentiometer, the duty cycle adjustment provision is integrated into the hardware. For three distinct blends, the duty cycle is set, and the average battery current is calculated for a steady charge. Throughout the cycle, the battery alone and a mixture of battery-ultracapacitor are used together for $0.5 \mathrm{~ms}$. The mode- 2 battery current is $1.60 \mathrm{~A}, 0.04 \mathrm{~A}$ for mode- 3 . It is calculated that the average battery current achieved for $1 \mathrm{~ms}$ with two modes is $0.82 \mathrm{~A}$.

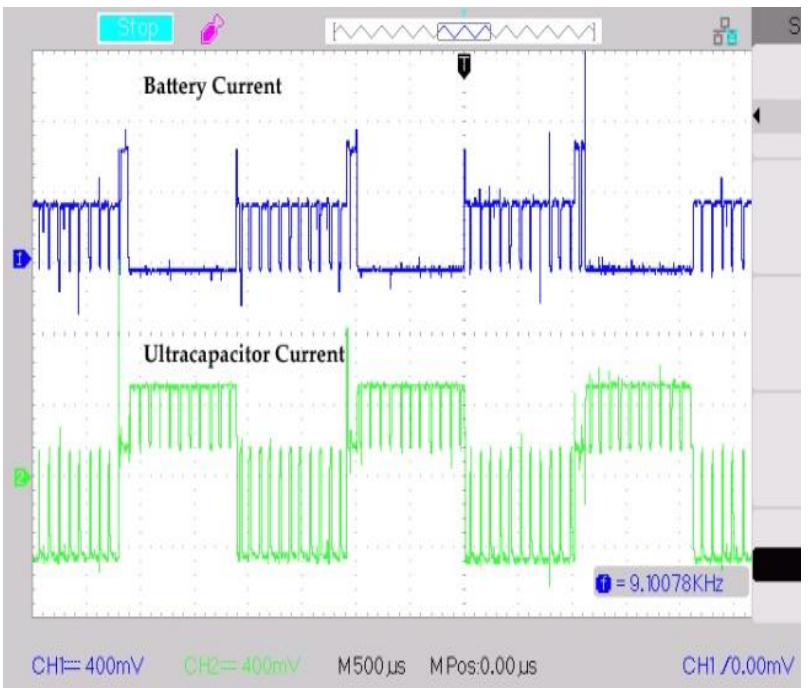

Fig.16. Battery and Ultracapacitor currentsmode-2 and mode- 3 with $t_{1}=0.5 \mathrm{mS}, t_{2}=0.5 \mathrm{mS}$.

Case-3: In this case, the load is fulfilled through individual ultracapacitor, battery and ultracapacitor together, and a single battery for $0.5 \mathrm{~ms}$ each. For mode- 3 , the battery current is $0.04 \mathrm{~A}$, for mode- 2 it is $1.6 \mathrm{~A}$, and for mode- 1 it is $2.8 \mathrm{~A}$. Average battery current calculated turns out to be $1.48 \mathrm{~A}$.

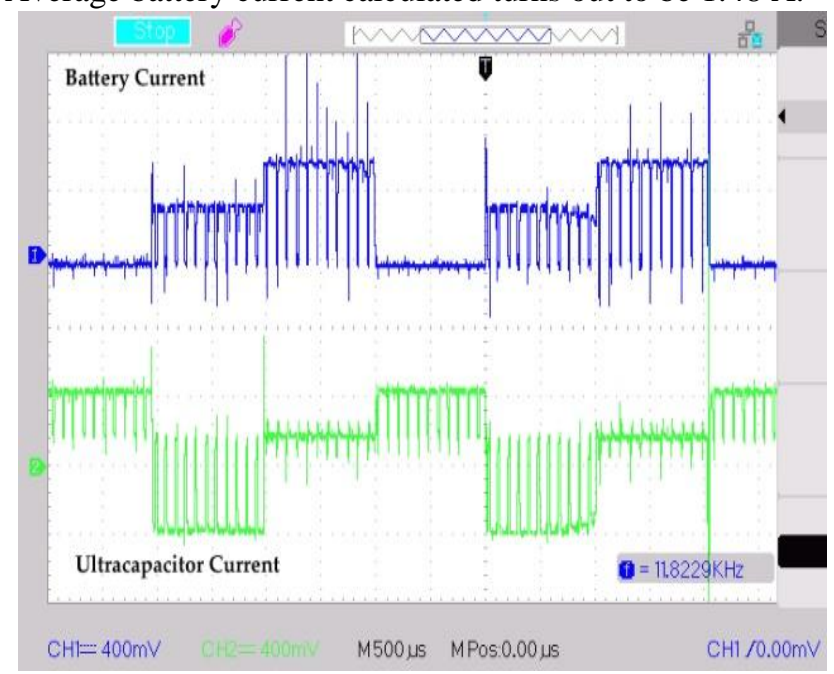

Fig.17. Battery and Ultracapacitor

currentsmode-3,mode- 2 and mode- 1 with $t_{1}=0.5$ ms, $t_{2}=0.5$ $\mathrm{ms}, \mathrm{t}_{3}=0.5 \mathrm{~ms}$.

Case-4 This case consists of the load is fulfilled through a battery, ultracapacitor together (mode-2) and individual battery (mode-1) for $0.5 \mathrm{~ms}$ each.

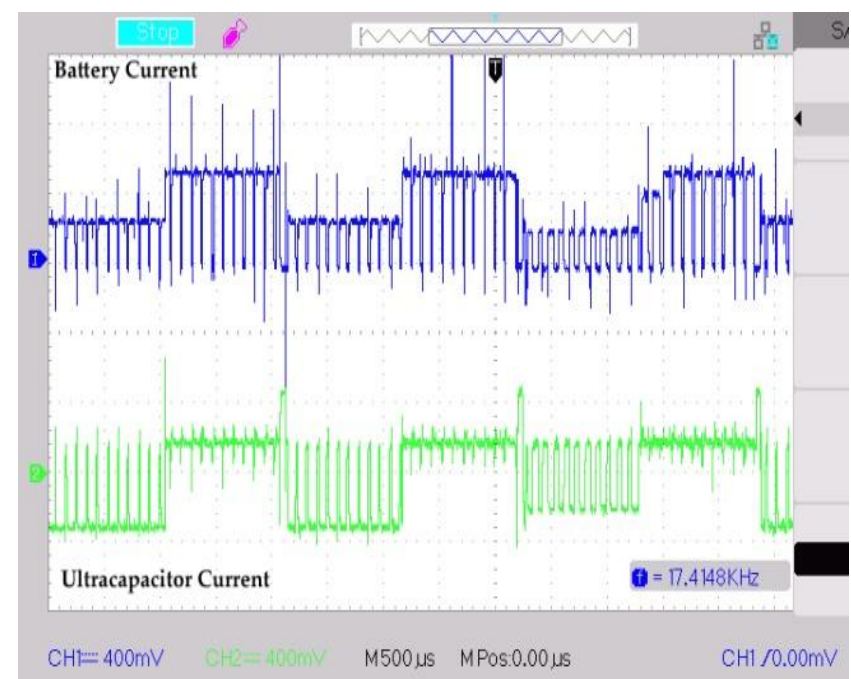

Fig.17. Battery and Ultracapacitor currentsmode-2, mode-1with $\mathrm{t}_{1}=0.5 \mathrm{~ms}, \mathrm{t}_{2}=0.5 \mathrm{~ms}$.

Above waveforms depict the load shared by battery alone, i.e., mode-1 (2.4A) and the load shared by battery and ultracapacitor, i.e.,mode- 2 are used together (1.2 A). The average battery current obtained with these modes (mode- 2 and mode-3) is $1.8 \mathrm{~A}$.

As an ultracapacitor is used to supply power demands of short duration, thereby mode- 3 can't be independently used for long term energy requirements.

Table 5.Current comparison for different cases.

\begin{tabular}{lllll}
\hline & $\begin{array}{l}\text { Case-1 } \\
\text { (Mode- } \\
\text { 1) }\end{array}$ & $\begin{array}{l}\text { Case-2 } \\
\text { (Mode-2 } \\
\mathbf{8 3})\end{array}$ & $\begin{array}{l}\text { Case-3 } \\
\text { (Mode- } \\
\mathbf{1 , 2 ~ \& ~ 3 ) ~}\end{array}$ & $\begin{array}{l}\text { Case-4 } \\
\text { (Mode-1 } \\
\mathbf{8 2}\end{array}$ \\
\hline $\begin{array}{l}\text { Average } \\
\text { Battery }\end{array}$ & $3 \mathrm{~A}$ & $0.82 \mathrm{~A}$ & $\begin{array}{l}1.48 \\
\text { Amp }\end{array}$ & $1.8 \mathrm{Amp}$ \\
$\begin{array}{l}\text { Current } \\
\text { Ultracapaci } \\
\text { tor Current } \\
\text { (Dischargi } \\
\text { ng) }\end{array}$ & $0 \mathrm{~A}$ & $2 \mathrm{~A}$ & $2 \mathrm{~A}$ & $1.6 \mathrm{~A}$ \\
\hline
\end{tabular}

Here we use standard mode (energy-supplying battery) or blended mode in which ultracapacitor alone and battery-ultracapacitor sharing can be preferred to minimize average battery current. The minimization of battery current increases the electric vehicle's operating cycle/driving cycle (or any load). Mixed mode (case-2) provides an average current of 0.82 A compared to the individual battery mode, which provides an average battery current of $3 \mathrm{~A}$, obviously showing an average battery current of 27.33 percent $\left(0.82 \mathrm{~A}^{*}\right.$ $100 / 3$ A) compared to tooth control modes (case-1), resulting in a much enhanced driving cycle range.

The experimentation work is performed using a small prototype energy management system composed of the differential probe Battery, Ultracapacitors, Control Board, Power Supply, Digital Storage Oscilloscope. 


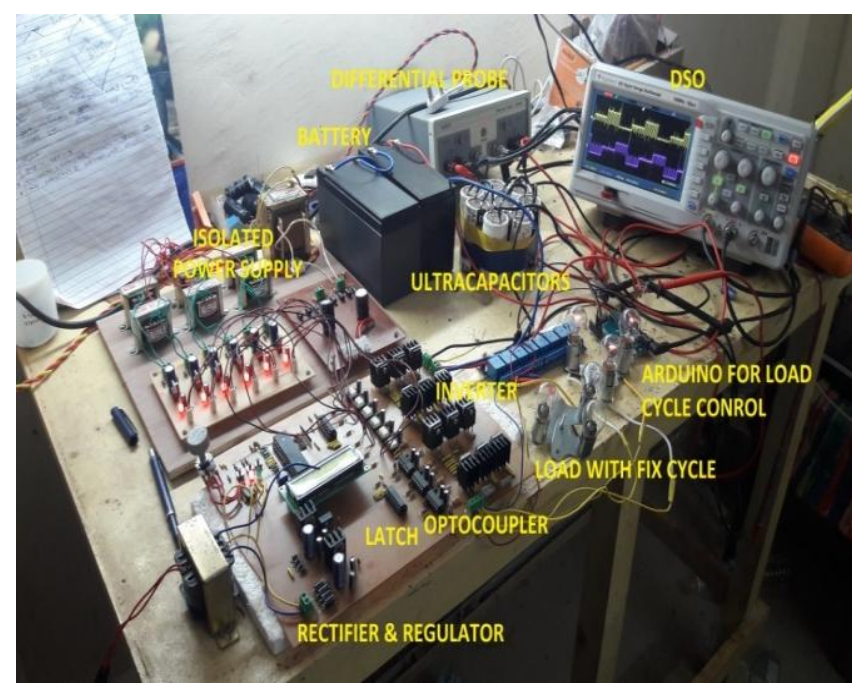

Figure 18.Experimental Setup.

With experimental results hardware tested for different cases with mode-1-, mode-2, and mode-3.

\section{CONCLUSION}

Appropriate multi-source inverter topology was suggested for HESS in this paper. This topology has the primary benefit of not adding any new stages between grid/motor and battery. The result of the novel multi-source connection is improved energy demand load fulfillment, thus enhancing electric vehicle efficiency. Smooth present sharing and lower average currents are also accomplished with multi-source inverters. On the other side, the battery can drive an engine directly without any boost operation as per the DC / DC converter, thereby lowering the generic converter price and also improving the effectiveness of EMS. During dynamic load requirements acquired using the SVPWM-based control approach, which increases load stability as an induction motor, active power, and energy sharing between multisource is feasible. Finally, a scaled-down prototype is used to study the efficiency of multisource inverter topology. From experimentation, it is noted that with multisource topology, the higher driving range is achieved with a decrease of the average current to 27 percent compared to the current from the battery during standard methods of EMS control with higher heat stability, reduction in overall size and improvement of the life of the power storage system.

\section{REFERENCES}

1. Paulo G. Pereirinha and João P. Trovão, "Multiple Energy Sources Hybridization: The Future of Electric Vehicles?", chapter 8 p.p.237-262 http://dx.doi.org/10.5772/53359, New Generation of Electric Vehicles IntechOpen, $19^{\text {th }}$ December 2012.

2. Andrew F. Burke, "Batteries and Ultracapacitors for Electric, Hybrid, and Fuel Cell Vehicles," Proceedings of the IEEE, Volume: 95, Issue: 4, April 2007, DOI: 10.1109/JPROC.2007.892490 Publication 30 April 2007.

3. Dirk Uwe Sauer; Martin Kleimaier; Wolfgang Glaunsinger, "Relevance of energy storage in future distribution networks with high penetration of renewable energy sources," CIRED 2009- 20th International Conference and Exhibition on Electricity Distribution Part 1,p.p.1 - 4, 2009.

4. KanAkatsu; Naoki Watanabe; Masami Fujitsuna; Shinji
Doki; Hiroshi Fujimoto, "Recent related technologies for EV/HEV applications in JAPAN," IEEE ECCE Asia Downunder, p.p.141 - 146, 2013.

5. Srdjan M. Lukic, Jian Cao, Ramesh C. Bansal, Fernando Rodriguez, and Ali Emadi, "Energy Storage Systems for Automotive Applications," IEEE Transactions On Industrial Electronics, Vol. 55, No. 6 June 2008.

6. Deepak Somayajula and Mariesa L. Crow, “ An Integrated Active Power Filter-Ultracapacitor Design to Provide Intermittency Smoothing and Reactive Power Support to the Distribution Grid," IEEE Transactions On Sustainable Energy, Vol. 5, No. 4, pp.1116-1125, October 2014.

7. S. Manfredi, M. Pagan and. Raimo, "Ultracapacitor-based Distributed Energy Resources to support time-varying smart-grid power flows," International Symposium on Power Electronics, Electrical Drives, Automation and Motion,pp.1148-1153, 2012.

8. Li X., Zhang L., Wang Z., \& Dong P., "Remaining useful life prediction for lithium-ion batteries based on a hybrid model combining the long short-term memory and Elman neural networks," Journal of Energy Storage, 21, 510-518.doi:10.1016/j.est.2018.12.011, 2019.

9. Zhang J., Zhang L., Sun F., \& Wang Z., "An Overview on Thermal Safety Issues of Lithium-ion Batteries for Electric Vehicle Application," IEEE Access, 6, 23848-23863.doi:10.1109/access.2018.2824838, 2018.

10. Li X., Wang Z., Zhang L., Zou C., \&Dorrell D. D., "State-of-health estimation for $\mathrm{Li}$-ion batteries by combing the incremental capacity analysis method with grey relational analysis," Journal of Power Sources, 410-411, 106-114.doi:10.1016/j.jpowsour.2018.10.069, 2019.

11. Z. Wang, J. Ma, L. Zhang, "State-of-health estimation for lithium-ion batteries based on the multi-island genetic algorithm and the Gaussian process regression," IEEE Access 5, 21286-21295, 2017.

12. L. Zhang, X. Hu, Z. Wang, F. Sun, J. Deng, D. Dorrell, Multi-objective optimal sizing of hybrid energy storage system for electric vehicles, IEEE Trans. Veh. Technol. 67(2), 1027-1035, Feb. 2018.

13. IlanAharon and AlonKuperman, "Topological Overview of Powertrains for Battery-Powered Vehicles With Range Extenders," IEEE Transactions On Power Electronics, Vol. 26, No. 3,pp.868-876, March 2011.

14. R.M. Schupbach, J.C. Balda, M. Zolot, B. Kramer, "Design methodology of a combined battery-ultracapacitor energy storage unit for vehicle power management," IEEE 34th Annual Conference on Power Electronics Specialist, PESC '03, 2003.

15. Ali Emadi, KaushikRajashekara, Sheldon S.Williamson, and Srdjan M. Lukic, "Topological Overview of Hybrid Electric and Fuel Cell Vehicular Power System Architectures and Configurations," IEEE Transactions On Vehicular Technology, Vol. 54, No. 3, pp. 763-770, May 2005.

16. J. Cao and A. Emadi, "A new battery/ultracapacitor hybrid energy storage system for electric, hybrid, and plug-in hybrid electric vehicles," IEEE Transaction on power electro. Vol.27no.1. pp.122-132, 2012.

17. S. M. Lukic S. G. Wirasingha, F. Rodriguez, C. Jian, and A. Emadi, "Power management of an ultracapacitor/battery hybrid energy storage system in an HEV," in Proc. VPPC, pp. 1-6, 2006.

18. L. Dorn-Gomba, P. Magne, B. Danen, and A. Emadi, "On the concept of the multi-source inverter for hybrid electric vehicle powertrains," IEEE Trans.On Electron.,pp. $1-1,2017$. 
19. Lea Dorn-Gombaand Ali Emadi, "A novel Hybrid Energy Storage System Using the Multi-Source Inverter," IEEE Transaction on Power Electron., pp.684-691,2018.

20. Soltani, M.; Ronsmans, J.; Kakihara, S.; Jaguemont, J.; Van den Bossche, P.; Van Mierlo, J.; Omar, N. "Hybrid Battery/Lithium-Ion Capacitor Energy Storage System for a Pure Electric Bus for an Urban Transportation Application," Appl. Sci. , doi: 10.3390/app8071176, 2018.

21. Xiangjun Li; LiangfeiXu; JianfengHua; Jianqiu Li; MinggaoOuyang; "Regenerative braking control strategy for fuel cell hybrid vehicles using fuzzy logic," International Conference on Electrical Machines and Systems,p.p.2712 - 2716, 2008 .

22. Wu, X.; Wang, T., "Optimization of Battery Capacity Decay for Semi-Active Hybrid Energy Storage System Equipped on Electric City Bus. Energies", doi: 10.3390/en10060792, 2017.

23. Xiangjun Li; LiangfeiXu; JianfengHua; Jianqiu Li MinggaoOuyang; "Control algorithm of fuel cell/battery hybrid vehicular power system," IEEE Vehicle Power and Propulsion Conference, p.p. $1-6,2008$.

24. Jiya, I.N.; Gurusinghe, N.; Gouws, R., "Combination of LiCs and EDLCs with Batteries: A New Paradigm of Hybrid Energy Storage for Application in EVs," World Electric. Veh. J., doi: 10.3390/wevj9040047, 2018.

25. Miñambres-Marcos, V.M.; Guerrero-Martínez, M.Á.; Barrero-González, F.; Milanés-Montero, M.I. A Grid Connected Photovoltaic Inverter with Battery-Supercapacitor Hybrid Energy Storage. Sensors, doi: 10.3390/s17081856, 2017.

26. Liu, J.; Jin, T.; Liu, L.; Chen, Y.; Yuan, K "Multi-Objective Optimization of a Hybrid ESS Based on Optimal Energy Management Strategy for LHDs," Sustainability 2017, doi: 10.3390/su9101874

27. Jiuyu Du; MinggaoOuyang; Hewu Wang, "Battery electric vehicle parameters design targeting to cost-benefit objective," IEEE Vehicle Power and Propulsion Conference, p.p. 1160 - 1164, 2012

28. João P. Trovão, Humberto M. Jorge, Paulo G. Pereirinha, "Design Methodology of Energy Storage Systems for a Small Electric Vehicle," EVS24 Stavanger, Norway, May 13-16, 2009

29. Joao Pedro F Trovao, Victor DN Santos, Carlos HenggelerAntunes, Paulo G Pereirinha, Humberto M Jorge, "A real-time energy management architecture for multisource electric vehicles," IEEE Transactions On Industrial Electronics, p.p. 3223-3233, 2015. 